\title{
Influence of Group Guidance with Discussion Techniques on Local Learning Interest
}

\section{Yoppry Tanjung, Budi Astuti, and Andika Arisandi}

Universitas Negeri Yogyakarta

\section{Abstract}

This study aims to determine the effect of group guidance with discussion techniques on the interest in learning local content. This research method uses Experiments with 8 subjects of research, which is obtained from the results of questionnaire analysis that has been tested for validity as a support for an approach to teachers guidance and counseling. Data were analyzed quantitatively descriptively. The results of this Experimental study indicate that group guidance with discussion techniques can influence the interest in learning local content on 8 students who are subject. Score of interest in learning local content before being given an action (pre-test) that is 43 in the low category. After being given an action (post-test) the score was 55 which

Corresponding Author: Yoppry Tanjung yoppryhn@yahoo.co.id

Received: 2 May 2019 Accepted: 19 June 2019 Published: 3 July 2019

Publishing services provided by Knowledge E

(c) Yoppry Tanjung et al. This article is distributed under the terms of the Creative Commons

Attribution License, which permits unrestricted use and redistribution provided that the original author and source are credited.

Selection and Peer-review under the responsibility of the ICMEd Conference Committee.

\section{G OPEN ACCESS} was categorized as moderate. Thus it can be recommended that group guidance with discussion techniques can influence the interest in learning local content for students in the school.

\section{Keywords: Local Learning Interests, Group Guidance Services, Discussion Techniques}

\section{Introduction}

Education is a fundamental human symptom in human life to deliver human children to the world of civilization. It is also an existential human guidance and authentic guidance, so that children recognize their unique identity, are able to survive to possess and continue or develop the previous generation's social heritage to be built through reason and experience.

Learning interest forms certain academic attitudes that are very personal to each student. Therefore, learning interest must be grown by each student himself. The other party only strengthens and fosters interest or to maintain the interest that someone has. Interest is related to certain values. Therefore, reflecting on the values in learning activities is very useful to arouse interest. For example learning to pass an exam, becoming a champion, an expert in one of the sciences, fulfilling a curiosity to get a degree or getting a job. 
Local content is the subject matter and the introduction of various regional characteristics, not only consisting of skills, crafts, but also manifestations of regional legends and customs. The existence of local content subjects is a form of education in each region which has more relevance to the situation and needs of the region concerned. This is in line with efforts to improve the quality of national education so that the existence of the local content curriculum supports and complements the national curriculum (Soewardi, 2008, makalahdanskripsi.blogspot.com).

Group guidance is an activity carried out by a group of people by utilizing group dynamics. That is, all participants in group activities interact with each other, are free to express opinions, respond, give suggestions, etc.; what was discussed was all useful for the participants themselves and for other participants. By using group guidance services with discussion techniques greatly influence and help students who have interest in learning on low local content to be improved and streamlined, (Prayitno, 2004: 309).

Based on the results of direct observations while carrying out the Case Study at Palembang's 19th State Junior High School, the fact in the field that the school did not have special hours for the implementation of Guidance and Counseling. So the tutor teacher enters the class only when the subject teacher is unable to enter the class. The report obtained from the teacher's guidance and counseling at the school, that there are still many problems faced by students regarding the interest in learning which is still classified as ineffective, including learning in local content subjects, which are divided into regional crafts and BTQ (Read Write Qur ' an). In this study the researcher focused on students who have low learning interest in local content subjects, especially local crafts, namely drawing in accordance with the provisions learned such as drawing diarton using watercolors, drawing using tools such as paint and glass to produce pictures or paintings, like pictures of traditional houses.

Interest in learning about regional crafts, such as drawing there are still many students who have low learning interest or no interest in trying to learn and practice at home or at school. This can be shown by the difference in low learning interests that affect the achievement value of each student, there are those above the class average, below the class average and some are right on the class average line. This fact encouraged researchers to specifically provide group guidance services in the form of Experimental Research to increase interest in learning local content through group guidance services with discussion techniques. 


\section{Literature Review}

According to Dalyono (2010: 227) that interests related to learning habits that are not good will affect the expected needs of problem-solving abilities using strategy considerations. The need to foster good learning interest arises from the urge to give satisfaction to an instinct. Children's interest in certain objects can arise from various sources including instinct and desire development, intellectual functions, environmental influences, experiences, habits, education and so on.

According to R.Gagne (in Susanto, 2013: 1), learning can be defined as a process in which an organism changes its behavior as a result of experience. Learning and teaching are two concepts that cannot be separated from each other. These two concepts become integrated in one activity where there is interaction between the teacher and students, as well as students with students during learning. According to Winkel (in Khairani, 2013: 5), stating learning is a process of behavioral change that is done intentionally to get better change, for example: from not knowing to knowing, from being unskilled to being skilled, from not being able to do something to being able do something and so on. According Mudzakir (in Khairani, 2013: 4), expressing learning is a business or activity that aims to make changes in a person, including changes in behavior, attitudes, habits, knowledge, skills and so on.

According to Susanto (2013: 25), argued that the interest in learning is a mental framework that stands from a combination of motion in combination and a mixture of feelings, feelings, anxiety and other tendencies that commonly direct individuals to a particular choice.

According to Arifin (2011: 208) suggests that local content is a set of plans and arrangements regarding the objectives, contents and learning materials compiled by education units in accordance with the diversity of regional potential, regional characteristics, regional advantages, regional needs, and their respective environments and ways which is used as a guide to the implementation of learning activities to achieve certain educational goals. Local content leads to education programs in the form of subjects whose content and media delivery are related to the natural environment, social environment, and cultural environment as well as regional needs that must be studied by students in the area.

According to Soewardi (2008, makalahdanskripsi.blogspot.com) local content is subject matter and the introduction of various regional characteristics, not only those which consist of skills, crafts, but also manifestations of legendary regional cultures and customs. Local content needs to be given to students so that students are more 
knowledgeable and love their own regional culture, noble character, independent, creative and professional, which in turn can foster a sense of love for the culture of the country.

According to Prayitno (2004: 309) suggests that group guidance is an activity carried out by a group of people by utilizing group dynamics. Group guidance at school is an information activity for a group of students to help them develop the right plans and decisions. That is, all participants in group activities interact with each other, are free to express opinions, respond, give suggestions, etc.; what was discussed was all useful for the participants themselves and for other participants

Meanwhile, according to (Sukardi, 2008: 64) group guidance services are intended to enable students to collect various materials from resource persons (especially tutors) who are useful for everyday life both as individuals and as students, family members and society.

According to Prayitno (in Sukardi, 2008: 65) group guidance services utilize group dynamics to achieve the goals of guidance services. In order for the group to take place in the group, it can effectively benefit the coaches of the groups and group members.

\section{Material \& Methodology}

Research is a scientific way to get data with specific goals and uses (Sugiyono, 2012: 1). The method that will be used in this research is the experimental method. Arikunto (2006: 3 ) states, the experimental method is a way to find a causal relationship (clausal relationship) between two factors deliberately generated by the researcher by eliminating or reducing other disturbing factors.

In this experimental research method, researchers chose to use the 'One-Group Pretest-Posttest Design' experimental design. In the experimental design of 'One-Group Pretest-Posttest Design', that the results of the treatment can be known more accurately, because it can compare with the state before being treated. Subjects are data sources that answer problems. Subjects in this study were known through direct observation and information from the guidance and counseling teachers in Palembang's 19th State Junior High School and through the results of questionnaire analysis that would be given to students, so that the research subjects were 8 students, then formed in a group. The subjects of this study were students who had low learning interest in local content subjects in their classrooms 


\section{Results and Discussion}

\subsection{Result}

Based on the results of the questionnaire interest in learning local content for students of class IX 3 before being treated on October 28, 2014 and after treatment on November 27,2014 . Then the questionnaire was analyzed by researchers so that the results of student interest questionnaire can be seen in local content subjects as the following:

TABLE 1: 1. Score about aspects of preference in local content lessons.

\begin{tabular}{|l|c|}
\hline No & $\begin{array}{c}\text { Research } \\
\text { subject }\end{array}$ \\
\hline 1 & AN \\
\hline 2 & RU \\
\hline 3 & AZ \\
\hline 4 & AR \\
\hline 5 & JU \\
\hline 6 & DE \\
\hline 7 & MA \\
\hline 8. & AL \\
\hline Total Score
\end{tabular}

\begin{tabular}{|c|}
\hline \\
\hline Score \\
\hline 11 \\
\hline 8 \\
\hline 9 \\
\hline 7 \\
\hline 10 \\
\hline 9 \\
\hline 8 \\
\hline 10 \\
\hline $72: 8=9$ \\
\hline
\end{tabular}

Pre-test

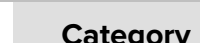

all right

low

low

Very low

low

low

low

low

low

\begin{tabular}{|c|c|}
\hline \multicolumn{2}{|c|}{ Post-test } \\
\hline Score & Category \\
\hline 14 & high \\
\hline 11 & all right \\
\hline 12 & all right \\
\hline 10 & low \\
\hline 13 & all right \\
\hline 12 & all right \\
\hline 11 & all right \\
\hline 13 & all right \\
\hline $96: 8=12$ & all right \\
\hline
\end{tabular}

Based on the results scale of interest in learning local content, the comparison score of pre-test and post-test on the aspect of pre-test score preference was 9 in the low category, after being given treatment there was a change in the post-test score which was 12 in the medium category. Based on the comparison scores of pre-test and posttest, AR which has a pre-test 7 score is included in the very low category, after being treated the changes occur in AR which has a post-test score of 10 included in the low category, AR has an increase in scores and more looks active after being treated. $\mathrm{RU}$ and MA which have a pre-test score 8 are included in the low category, after being treated, there is a change in RU and MA which has a post-test score of 11 included in the medium category, RU and MA have increased scores and are questionable and active in discussion activities group. $A Z$ and $D E$, which had a pre-test score of 9, were in the low category, after being treated, there was a change in $A Z$ and $D E$ which had a post-test score of 12 included in the moderate category, $A Z$ and DE experienced an increase in scores and were more active after being treated. JU and $\mathrm{AL}$ who had a pre-test score of 10 were included in the low category, after being treated, there was a change in JU and $A L$ who had a post-test score of 13 included in the medium category, JU and AL experienced an increase in scores and were more likely to like learning lessons. local 
after being treated. AN had a pre-test score of 11 included in the low category, after being treated, there was a change in $\mathrm{AN}$ who had a post-test score of 14 included in the high category, AN had an increase in score and was more active after being treated, AN seemed to prefer to learn content local and take active group discussion activities.

TABLE 2: 2. Score about aspects of interest in local content lessons.

\begin{tabular}{|l|l|}
\hline No & Research subject \\
\hline 1 & AN \\
\hline 2 & $\mathrm{RU}$ \\
\hline 3 & $\mathrm{AZ}$ \\
\hline 4 & $\mathrm{AR}$ \\
\hline 5 & $\mathrm{JU}$ \\
\hline 6 & $\mathrm{DE}$ \\
\hline 7 & $\mathrm{MA}$ \\
\hline 8 & $\mathrm{AL}$ \\
\hline Total Score & \\
\hline
\end{tabular}

\begin{tabular}{|c|c|}
\hline \multicolumn{2}{|c|}{ Pre-test } \\
\hline Score & Category \\
\hline 16 & low \\
\hline 13 & low \\
\hline 16 & low \\
\hline 15 & low \\
\hline 15 & low \\
\hline 16 & low \\
\hline 13 & low \\
\hline 16 & low \\
\hline $120: 8=15$ & low \\
\hline
\end{tabular}

\begin{tabular}{|c|c|}
\hline \multicolumn{2}{|c|}{ Post-test } \\
\hline Score & Category \\
\hline 19 & all right \\
\hline 16 & low \\
\hline 19 & all right \\
\hline 18 & all right \\
\hline 18 & all right \\
\hline 19 & all right \\
\hline 16 & low \\
\hline 19 & all right \\
\hline low & all right \\
\hline
\end{tabular}

In the aspect of interest in the pre-test score, 15 included in the low category, after being given a treatment there was a change in the post-test score which was 18 in the medium category. This shows that there is an increase in scores from low to medium categories. Based on the comparison score of the pre-test and post-test, $R U$ and MA which had a pre-test score of 13 included in the low category, after being given treatment there was a change in RU and MA which had a post-test score 16 included in the low category, RU and MA experiencing an increase in score and more active after being treated. AR and JU which had a pre-test score of 15 were included in the low category, after being treated the changes occurred in $A R$ and $J U$ which had a post-test score of 18 included in the moderate category, AR and $\mathrm{JU}$ had increased scores and were more interested in learning content lessons. local after being treated. $A N, A Z, D E$, and $A L$ who had a pre-test score of 16 included in the low category, after being given treatment there were changes in AN, AZ, DE and AL which had a post-test score of 19 included in the medium category, there was a better change, such as being more interested and active in group discussion activities.

In the aspect of attention the pre-test score is 10 in the low category, after being treated the changes occur in the post-test score, which is 14 in the high category. This shows that an increase in scores from low predicate to high. Based on the comparison score of the pre-test and post-test, MA which has a pre-test score of 8 is included in the low category, after being given a treatment there is a change in the MA which has a posttest score of 10 included in the low category, MA looks more attention during the activity 
TABLE 3: 3. Score about aspects of attention on local content lessons.

\begin{tabular}{|l|l|}
\hline No & Research subject \\
\hline 1 & AN \\
\hline 2 & RU \\
\hline 3 & AZ \\
\hline 4 & AR \\
\hline 5 & JU \\
\hline 6 & DE \\
\hline 7 & MA \\
\hline 8 & AL \\
\hline Total Score & \\
\hline
\end{tabular}

\begin{tabular}{|c|}
\hline Pre-test \\
\hline Score \\
\hline 12 \\
11 \\
9 \\
\hline 8 \\
12 \\
10 \\
8 \\
10 \\
$80: 8=10$ \\
\hline
\end{tabular}

\begin{tabular}{l} 
test \\
Category \\
all right \\
all right \\
low \\
low \\
all right \\
\hline low \\
low \\
low \\
\hline low
\end{tabular}

\begin{tabular}{|c|c|}
\hline \multicolumn{2}{|c|}{ Post-test } \\
\hline Score & Category \\
\hline 16 & high \\
\hline 15 & high \\
\hline 13 & all right \\
\hline 12 & all right \\
\hline 16 & high \\
\hline 15 & high \\
\hline 10 & low \\
\hline 15 & high \\
\hline $112: 8=14$ & high \\
\hline
\end{tabular}

group discussion. AR which has a pre-test score of 8 is included in the low category, after being given a treatment there is a change in AR which has a post-test score 12 included in the medium category, AR looks more active and focused on learning local content lessons. AZ, which had a pre-test score of 9, was included in the low category, after being given treatment there was a change in $A Z$ that had a post-test score of 13 included in the medium category, AZ was more eager to express opinions. DE and AL who had a pre-test score of 10 were included in the low category, after being treated the changes occurred in DE and AL who had a post-test score of 15 included in the high category, ED and AL had increased scores and were more active after being treated. $\mathrm{RU}$ has a pre-test score of 11 included in the medium category, after being treated the changes occur in RU which has a post-test score of 15 included in the high category, $\mathrm{RU}$ is more concerned in learning activities after being given treatment. Furthermore, $\mathrm{AN}$ and $\mathrm{JU}$ which had a pre-test score of 12 were in the medium category, after being given treatment there were changes in $\mathrm{AN}$ and $\mathrm{JU}$ which had a post-test score of 16 included in the high category, $\mathrm{AN}$ and $\mathrm{JU}$ experienced an increase in scores and were more active in learning activities local content lessons after being treated.

In the aspect of involvement, the pre-test scores were 9 in the low category, after being given the treatment there was a change in the post-test score which was 11 in the medium category. This shows that there is an increase in scores from low categorical to moderate. Based on the comparison score of the pre-test and post-test, MA which has a pre-test score of 7 is included in the very low category, after being given a treatment there is a change in the MA which has a post-test score 9 included in the low category, but the MA has increased scores and more active after being treated. AZ and AR which had pre-test 8 scores were in the low category, after being treated there were changes in $A Z$ and $A R$ which had a post-test score of 10 included in the low category, $A Z$ and $A R$ 
TABLE 4: 4. Score about aspects of involvement in local content lessons.

\begin{tabular}{|l|l|}
\hline No & Research subject \\
\hline 1 & AN \\
\hline 2 & RU \\
\hline 3 & AZ \\
\hline 4 & AR \\
\hline 5 & JU \\
\hline 6 & DE \\
\hline 7 & MA \\
\hline 8 & AL \\
\hline Total score & \\
\hline
\end{tabular}

\begin{tabular}{|c|}
\hline \multicolumn{2}{|c}{ Pre-test } \\
\hline Score \\
\hline 11 \\
\hline 9 \\
8 \\
\hline 8 \\
10 \\
9 \\
7 \\
10 \\
$72: 8=9$ \\
\hline
\end{tabular}

\begin{tabular}{|c|}
\hline Category \\
\hline all right \\
\hline low \\
\hline low \\
\hline low \\
\hline low \\
\hline low \\
\hline Very low \\
\hline low \\
\hline low
\end{tabular}

\begin{tabular}{|c|c|}
\hline \multicolumn{2}{|c|}{ Post-test } \\
\hline Score & Category \\
\hline 14 & high \\
\hline 11 & all right \\
\hline 10 & low \\
\hline 10 & low \\
\hline 13 & all right \\
\hline 10 & low \\
\hline 9 & low \\
\hline 12 & all right \\
\hline $89: 8=11$ & all right \\
\hline
\end{tabular}

looked more focused in group discussion activities. DE which has a pre-test score of 9 is included in the low category, after being given treatment there is a change in DE which has a post-test score of 10 included in the low category, DE is not shy in issuing opinions and more daring. $\mathrm{RU}$, which has a pre-test score of 9, is included in the low category, after being treated with changes occurring in RU which has a post-test score 11 included in the medium category, RU's involvement in issuing opinions greatly influences other group members. AL had a pre-test score of 10 included in the low category, after being given treatment there was a change in $A L$ who had a post-test score of 12 included in the moderate category, $\mathrm{AL}$ experienced an increase in score and was more active after being treated. $\mathrm{JU}$ which has a pre-test score of 10 is included in the low category, after being treated, there is a change in $\mathrm{JU}$ which has a post-test score of 13 included in the medium category, JU looks more focused and actively participates in group discussion activities. AN, which has a pre-test score of 11 , is included in the medium category, after being treated, there is a change in $\mathrm{AN}$ who has a post-test score of 14 in the high category, AN experiences an increase in scores and is more active in group discussion after being treated.

\subsection{Discussion}

This study aims to determine the effect of guidance services with group discussion techniques on the interest in learning local content. To determine the effect of group guidance with discussion techniques, research activities were carried out by giving a pre-test that was giving questionnaires before treatment, giving treatment namely group guidance with discussion techniques, and giving post-tets namely giving questionnaires 
after treatment. The study was conducted on 28 October - 28 November 2014 at Palembang State 19 Middle School. The procedures in this study are as follows:

\subsubsection{Initial test (pre-test)}

The pre-test was conducted on 28 October 2014 by giving a questionnaire to students of class IX 3 in Palembang State 19 Junior High School, totaling 30 people to find out the students' interest in learning about local content subjects. At this stage the researcher collects research subjects by providing group guidance services, through the stages in group guidance, namely the formation stage, the transition stage, the activity stage and the termination stage. This formation phase aims to create an atmosphere or feeling of pleasure towards group members, this transition phase aims to see the readiness of the members to enter in the next stage, the activity phase to discuss the topics that will be submitted by the researcher, then at the end of the stage the researcher explains that group guidance will be terminated soon. Subjects were determined by taking 30 students from Palembang's Grade IX 3 Negari Middle School who were given a questionnaire according to the indicators of interest, namely: liking, interest, attention, involvement. Subjects that the researcher chose included in the criteria of low interest in learning, namely there were 8 students who had low learning interest in local content subjects.

\subsubsection{Treatment (treatment)}

On November 4, 2014 the first meeting was held to provide group guidance services with discussion techniques, namely the room of the Palembang State Junior High School 19. Researchers conduct treatment according to the stages in the group guidance, namely the formation stage, transition stage, activity stage and termination stage. This formation phase aims to create an atmosphere or feeling of pleasure towards group members, this transition phase aims to see the readiness of the members to enter in the next stage, the activity phase to discuss the topics that will be submitted by the researcher, then at the end of the stage the researcher explains that group guidance will be terminated soon. After finishing opening and introducing the group members to group guidance activities, the researcher gave the topic "About Learning Interests", namely discussing the meaning of learning interest, why learning interests are needed and what the consequences are if they do not have high learning interest. The group members who numbered 8 people to discuss to exchange ideas with group members 
discussed the topic of interest in learning. They look passive and more silent. When they finished discussing, representatives from the group expressed their opinions on the topic of interest in learning. This is done to invite members to share what they know about the topic to be discussed and invite students to share their emotions or feelings about the topic.

On November 13, 2014 in accordance with the previous planning, the second meeting was held at Palembang 19 State Middle School Mosque. Researchers conduct treatment according to the stages in the group guidance, namely the formation stage, transition stage, activity stage and termination stage. This formation phase aims to create an atmosphere or feeling of pleasure towards group members, this transition phase aims to see the readiness of the members to enter in the next stage, the activity phase to discuss the topics that will be submitted by the researcher, then at the end of the stage the researcher explains that group guidance will be terminated soon. After finishing opening and introducing the group members to the group guidance activities, the researcher gave the topic "About the Importance of Motivation in Learning Local Content Lessons", namely discussing the importance of motivation in learning local content lessons, why motivation in learning local content lessons is needed and what are the consequences if you don't have motivation in learning high local content lessons. They look still shy in issuing their opinions. When they finished discussing, representatives from the group expressed their opinions on the topic of the importance of motivation in learning local content lessons. This is done to invite members to share what they know about the topics to be discussed.

On November 18, 2014 researchers again provided guidance services with group discussion techniques in the room of the BK 19 Palembang State Junior High School with the topic of the importance of local content lessons in daily life. Researchers conduct treatment according to the stages in the group guidance, namely the formation stage, transition stage, activity stage and termination stage. This formation phase aims to create an atmosphere or feeling of pleasure towards group members, this transition phase aims to see the readiness of the members to enter in the next stage, the activity phase to discuss the topics that will be submitted by the researcher, then at the end of the stage the researcher explains that group guidance will be terminated soon. After completing the opening and introduction to the group members in participating in group guidance activities, the researcher gave the topic "About the Importance of Local Content Lessons in Daily Life", namely discussing the importance of local content lessons in daily life, why important local content lessons in everyday life and the consequences of not understanding the importance of local content lessons in daily 
life. Then the researchers continued the discussion of the topic at this third meeting by asking the group members to discuss again to exchange opinions with fellow group members on the topic of the importance of local content lessons in daily life. They look more active and enthusiastic in issuing their opinions. When they finished discussing, representatives from the group expressed their opinions on the topic of the importance of local content lessons in daily life. This is done to invite members to share about

\subsubsection{Final test (post-test)}

The post-test aims to see an increase in students' learning interest in local content subjects after being treated. The implementation was carried out on November 27 , 2014 in the classroom IX 3 Palembang State Junior High School 19.

Description of the research data analyzed is the result of a test about the interest in learning local content. There are three stages of data collection that are pre-test, treatment, and post-test to determine the effect of treatment or services provided.

Aspects of interest in learning local content in this study are grouped into 4, namely:

1. About aspects of preference in local content lessons

2. About aspects of interest in local content lessons

3. Regarding aspects of attention to local content lessons

4. Regarding aspects of involvement in local content lessons

\section{Conclusion}

From the results of the research and discussion that has been described, it can be seen that there are differences in scores between the results of the pre-test and the results of the post-test. The results of the pre-test showed that 8 students who were subjected to class IX 3 of SMP Negeri 19 Palembang had an interest in learning low local content. Furthermore, the results of the post-test showed that 8 students who were subjected to class IX 3 of SMP Negeri 19 Palembang had an interest in learning moderate local content. This means group guidance with discussion techniques influences the interest in learning local content for students in class IX 3 in Palembang State 19 Junior High School. In addition, during the process of giving group guidance with discussion techniques students look more active in discussing with a more relaxed atmosphere. 


\section{References}

[1] Ahmadi, Abu. 2009. Psikologi Umum. Jakarta: Rineka Cipta.

[2] Arifin, Zainal. 2011. Konsep dan Model Pengembangan Kurikulum. Bandung: PT Remaja Rosdakarya.

[3] Arikunto, Suharsimi. 2006. Prosedur Penelitian Suatu Pendekatan Praktik. Jakarta: Rineka Cipta.

[4] Budinigsih, Asri. 2012. Belajar dan Pembelajaran. Jakarta:Rineka Cipta.

[5] Dalyono, M. 2010. Psikologi Pendidikan. Jakarta:Rineka Cipta.

[6] Fernando, Refki. 2011. Kurikulum Muatan Lokal. http://refkifernando.blogspot.com. Diakses pada tanggal 8 Agustus 2014.

[7] Khairani, Makmun. 2013. Psikologi Belajar. Aswaja Pressindo:Yogyakarta.

[8] Loekmono. 2012. Ciri-Ciri Minat Belajar. http://dicari-saja.blogspot.com.Diakses pada tanggal 8 Agustus 2014.

[9] Loman Bolam, dkk., (2010). Pengantar Ilmu Pendidikan. Palembang: Unsri.

[10] No Name. 2013. Unsur-Unsur Minat. http://bagawanabiyasa.wordpress.com.

[11] Diakses pada tanggal 9 Juni 2014.

[12] Prayitno dan Erman Amti. 2004. Dasar-Dasar Bimbingan dan Konseling. Jakarta: PT. Rineka.

[13] Slameto. 2003. Belajar dan Faktor-Faktor Yang Mempengaruhinya. Jakarta: Rineka Cipta.

[14] Soewardi. 2008. PengertianMuatan Lokal. http://makalahdanskripsi.blogspot.com. Diakses pada tanggal 9 Juni 2014.

[15] Sudarmono. 1994. Minat Belajar. http://dicari-saja.blogspot.com. Diakses pada tanggal 5 juni 2014.

[16] Sugiyono. 2012. Metode Penelitian Pendidikan. Bandung: ALFABETA.

[17] Sukardi, Dewa ketut. 2008. Bimbingan dan Konseling di Sekolah. Jakarta: Rineka Cipta.

[18] Suryabrata, Sumadi. 2004. Psikologi Pendidikan. Jakarta: CV. Raja Grafindo Persada.

[19] Susanto, Ahmad. 2013. Terori Belajar Pembelajaran. Kencana: Jakarta.

[20] Syah, Muhibbin.2012. Psikologi Belajar. PT. RajaGrafindo Persada: Jakarta.

[21] Wisudita, Cokro. 2014. Lampiran II dan III Peraturan Menteri Pendidikan dan Kebudayaan Nomor 81a tahun 2013 tentang Implementasi Kurikulum. http:// cokrowisudita.blogspot.com.

[22] Diakses pada tanggal 8 Agustus 2014. 